\title{
ACCESSION TO THE MONETARY UNION AND SLOVENIAN MONETARY POLICY UNDER EXCHANGE RATE TARGETING
}

\author{
Peter MIKEK*
}

\begin{abstract}
:
After joining the EU in 2004, Slovenia and other new members will have to adopt the euro. Their accession to the European Monetary Union will require stabilizing and later fixing their exchange rates and thus restrictive monetary policy. The paper shows that successful stabilization of the exchange rate also requires restrictive fiscal policy. Fiscal policy that is not compatible with the goals of monetary policy would prevent stabilization of the exchange rate.
\end{abstract}

Keywords: fiscal regime, monetary union, monetary policy reaction function, monetary feedback, exchange rate targeting, inflation targeting, price level

JEL Classification: E50, E60, F40

\section{Introduction}

In 2004 Slovenia, along with a few other new members, joins the EU and therefore will also soon be joining the European Monetary Union (EMU). This necessarily means restrictive monetary policy prior to accession and especially during the ERM2 (new Exchange Rate Mechanism) period. This is especially true for Slovenia because of its relatively high inflation rates. Fixing the exchange rate and losing monetary sovereignty means that the government will be much more tempted to use fiscal policy for the stabilization of business cycles. In this paper I therefore ask what fiscal regime would be compatible with the necessary stabilization of the exchange rate. I investigate whether the effects of temporary monetary and fiscal shock depend on the interactions between both policies.

For Slovenia "the choice of the strategy for the EMU accession is among the most important economic and political decisions" (Mencinger, 2002, p. 22). But the Slovenian economy still differs substantially from the economies of other European countries. As can be seen from Table 1, real gross domestic product (GDP) per capita in Slovenia (adjusted for price level differences), at 17,291 USD, still does not reach the lowest figures among other European countries and is well below the European average (25,200 - see IMAD, 2003). Productivity between $1995-2002$

*) School of Economics and Business, University of Maribor, Razlagova 20, 2000 Maribor, Slovenia (email: PETER.MIKEK@UNI-MB.SI). 
increased by $28 \%$, which exceeded the productivity growth in the EU but lagged behind the average for new EU members (see EC, 2003). Catching the EU average would thus take more than 13 years if dynamics continued at the current rate. The unemployment rate in 2002 was $7.4 \%$ in Slovenia and $6.4 \%$ in the EU (IMAD, 2003).

Table 1

Per Capita Real GDP in Some Small European Countries in 2001 (PPP based)

\begin{tabular}{|l|c|}
\hline Austria & 27,800 \\
\hline Denmark & 29,900 \\
\hline Finland & 25,900 \\
\hline Greece & 17,800 \\
\hline Ireland & 31,400 \\
\hline Portugal & 18,700 \\
\hline EU-15 & 25,200 \\
\hline Czech Republic & 15,090 \\
\hline Hungary & 13,430 \\
\hline Poland & 10,320 \\
\hline Slovenia & 17,291 \\
\hline
\end{tabular}

Source: IMAD, 2003.

What would be an appropriate combination of monetary and fiscal policy that would facilitate the stabilization of the exchange rate? The theoretical framework of our discussion is the fiscal theory of the price level determination. The price level depends on aggregate government liabilities. They affect the aggregate consumption levels and therefore aggregate demand and the price level (see Leeper, 1991; Sims, 1994; Woodford, 1994, 1996, Loyo, 1997, Cochrane, 1998, Bergin, 1998; Daniel, 2001 and others). This is rather different than the game theory approach of Stackelberg leader played by one or the other policy (see Sargent and Wallace, 1981). In this approach the growth of public debt signals future seignorage. Agents with rational expectations take this into account and this causes inflation now. The fiscal view, however, emphasizes the wealth effects of the changes in public debt. Therefore inflation may occur very quickly even if the central bank never accommodates an expansionary fiscal policy. In this way the government intertemporal budget constraint is fulfilled through adjustments in the current real value of assets.

I study the interactions of fiscal and monetary policy in a two-country model that includes specification of both fiscal and monetary feedback. To elicit the main claims, I simulate the impulse responses to a monetary and to a fiscal shock. Based on these, I conclude that a compatible fiscal policy is a necessary condition for the successful stabilization and fixing of the exchange rate at the moment of accession to the EMU.

The paper is structured in the following way: in Section 2 I discuss some features of Slovenian monetary policy. I present the specification of the fiscal policy in Section 3. The simulation results are discussed in Section 4. 


\section{Specification of Monetary Policy}

Slovenian central bank declared that "preparation of conditions for adopting the euros as soon as possible remains the most important priority of the Bank of Slovenia" (BaS, 2003, p. 6). This brings about the focus on the exchange rate. The country that wishes to participate in ERM2 ${ }^{1)}$ will have to keep its exchange rate within a $15 \%$ band around the set exchange rate of the euro (see Corker et al., 2000). Thus approaching the EMU and during ERM2 period, the monetary authority will have to strive to lower the volatility of the exchange rate.

The central bank has already been doing that. In Figure 1 standard deviations of the exchange rate of tolar/euro from January 2000 to October 2003 are presented. The figure clearly illustrates successful stabilization of the exchange rate. The volatility during the observed period was relatively small and has decreased substantially since 2000 .

Figure 1

Standard Deviations for the Exchange Rate of tolar/EUR (monthly)

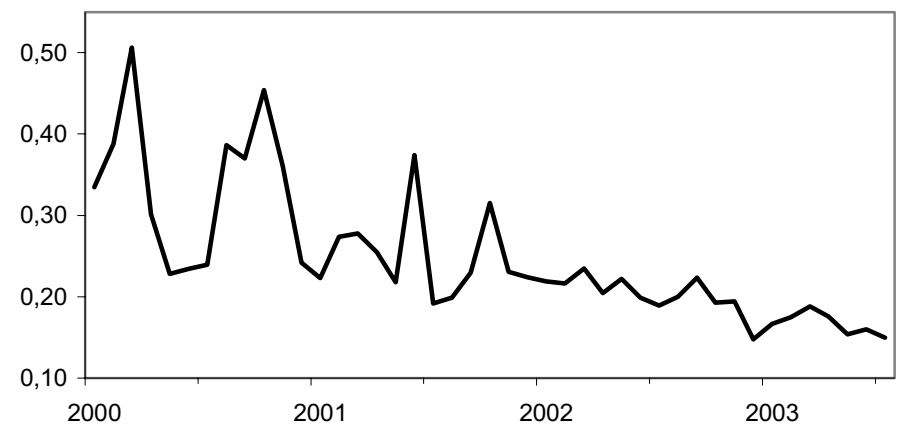

Source: BS, 2003; own calculations.

The substantial gap between the inflation rates in Slovenia and Europe is shown in Figure 2. The difference is gradually decreasing, ${ }^{2)}$ but still does not meet the Maastricht criterion for inflation rate. The trend implies about a $1.5 \%$ annual decrease during the period. For 2003 the estimated inflation rate in Slovenia is between 5 and $6 \%$ (see IMAD, 2003). ${ }^{3)}$ For 2003 the central bank estimates inflation at about $3.5 \%$ (see BaS, 2003).

The Bank of Slovenia has already been implementing a policy of gradual depreciation. Mencinger and Mrak (2003) point out that: "Managed floating should therefore remain the pillar of monetary policy until a credible commitment to peg enables fast passage from the ERM2 to the EMU, which would shorten the period of uncertainty" (p. 2). Additionally, the central bank writes that at the time of entering the ERM2 "given approximately equal levels of nominal interest rates, the monetary policy will be directed towards keeping the interest parities within magnitudes that

1) Participation of Slovenia in the ERM2 is expected from the end of 2004 (see BaS, 2003).

2) Some authors discuss the Ballasa-Samuelson effect as the reason behind this discrepancy (check Mencinger, 2003 or Bole, 2001).

3) In October 2003 the figure for the EU stands at $2.1 \%$. 
do not encourage speculative flows of hot capital and therefore do not cause major fluctuations of the exchange rate" (BaS, 2003, p. 49). This implies the specification of monetary policy incorporating the response to changes in the exchange rate, as can be seen in equation (1):4)

$$
R_{t}=\phi_{1}+\alpha D_{t}+\phi_{2} y_{t}+\theta_{t}
$$

The nominal interest rate $\left(R_{t}\right)$ is the instrument, $D_{t}$ represents depreciation rate, $y_{t}$ output, $\theta_{t}$ is stochastic normally distributed shock to monetary policy, $\alpha$ and $\phi_{i}^{\prime} s$ are parameters. According to (1), the central bank tries to achieve the desired depreciation by changing the instrument. Large $\alpha$ shows the stabilization efforts of the central bank and describes the relative importance of this goal. Such a reaction function will necessarily be implemented during the ERM2 participation or even earlier. The policy maker may also respond to a fluctuation of output $\left(\phi_{2}^{\prime} y_{t}\right),{ }^{5}$ where $\phi_{2}^{\prime}$ shows the relative importance of output stabilization versus exchange rate stabilization.

Figure 2

Inflation Rate in Slovenia and the EU-15 (annualized monthly rates, June 2001-June 2003)
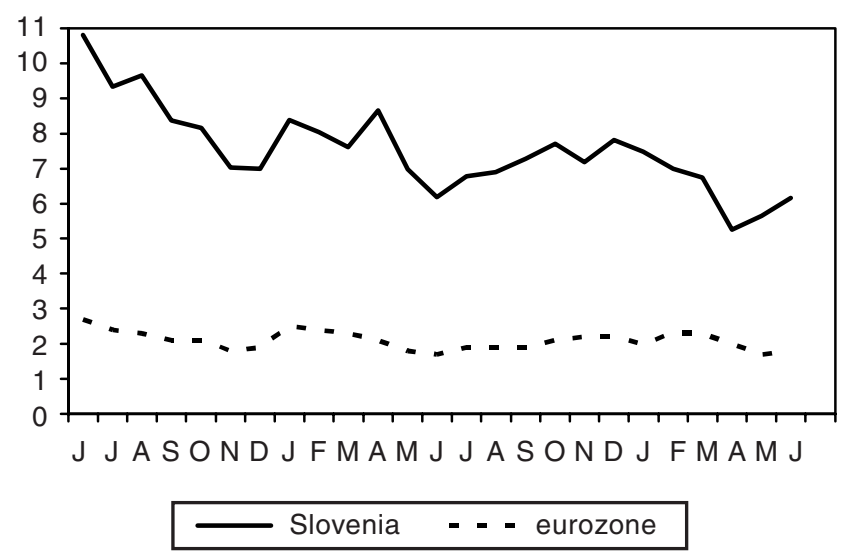

Source: SURS, EUROSTAT, 2003.

The Slovenian monetary policy is summarized in Bole (2003): "By targeting real interest rate, the central bank regulates the restrictivity of the monetary policy by squeezing the home consumption and through this the final goal of lowering the growth of prices for non-tradables. Based on the forecasted (given) inflation expectation, the central bank has to set the nominal interest rates (for tolar instruments) so high as to achieve the desired restrictivity" (p. 37). $\left.{ }^{6}\right)$ At first sight this seems to be in disagreement with equation (1). However, the changes of the exchange rate feed into the inflation rate and directly affect the expected inflation rate. First order conditi-

4) Bole (2003) also proposes a specification as in equation (1).

5) Svensson (1988) also includes this type of element in the reaction function.

6) To keep the model simple, and since it doesn't change the results, the distinction between tradables and non-tradables is not introduced. 
ons of the model ${ }^{7}$ imply that the uncovered interest parity holds. Therefore the inflation rate and the exchange rate are determined simultaneously. Additionally, Bole (2003) discusses an alternative specification which closely resembles equation (1). In his specification the monetary authority maintains a desired fixed exchange rate or at least tries to stabilize it. ${ }^{8)}$

7) The model is similar to the one in Obstfeld and Rogoff (1995) and Woodford (1996).

Household maximizes:

$$
u(c, m, I)=E_{0} \sum_{t=0}^{\infty} \beta^{t}\left(\ln c_{t}+\omega \ln m_{t}-v\left(I_{t}\right)\right)
$$

s.t. the following budget constraint:

$$
\begin{gathered}
c_{t}+\tau_{t}+m_{t}+b_{t}^{h h}+e_{t} b_{t}^{\text {th }}=w_{t} l_{t}+s_{t}+m_{t-1} \pi_{t}^{-1}+R_{t-1}^{h} \pi_{t}^{-1} b_{t-1}^{h h}+e_{t} R_{t-1}^{t} \pi_{t}^{-1} b_{t-1}^{t h} \\
\frac{p_{t}^{p h}}{p_{t}^{h}} y_{t}=w_{t} I_{t}+s_{t} ; \quad I_{t}=\int_{0}^{n} I_{t}(z) d z
\end{gathered}
$$

where $w_{t}$ is real wage, $s_{t}$ is profit and $I_{t}$ represents hours or labour. Real income $\left(p_{t}^{p i} / p_{t}^{i}\right) y_{t}$ and the ratio $\left(p_{t}^{p i} / p_{t}^{i}\right)$ is the relative price of good $i . v$ is an increasing convex function. Composite consumption good $\left(c_{t}\right)$ is given as in Dixit and Stiglitz (1977):

$$
c_{t}^{j}=\left[\int_{0}^{1} c_{t}^{j}(z)^{\frac{\mu-1}{\mu}} d z\right]^{\frac{\mu}{\mu-1}}
$$

In equation (3), $m$ represents real money stock, $b^{\text {hh }}$ are one period risk-free home bonds held at home denominated in domestic currency, $b^{\text {th }}$ foreign bonds held at home denominated in foreign currency, $R^{h}$ domestic gross nominal interest rate, and $R^{f}$ foreign gross nominal interest rate $R^{f} . \tau$ is the real value of lump-sum taxes, $\pi_{t}$ is the gross rate of inflation, and $D_{t}$ is the gross depreciation rate.

Producers from $[0, n]$ inhabit the home economy and those from $[n, 1]$ are abroad. With probability $\rho$, the producer may not be able to choose the optimal price in period $t$ (see Calvo, 1983). The producer maximizes the expected discounted future profits:

$$
\max _{N_{t}} E_{t} \sum_{s=0}^{\infty} \rho^{s}\left[\frac{N_{t} y_{t+s}(z)-W_{t+s} y_{t+s}(z)}{\prod_{k=1}^{s} R_{t+k}}\right]
$$

where $N_{t}$ is the new price chosen in period $t$, and $y_{t+s}(z)$ represents the demand for good $z$ at time $t+s$. $W_{t}$ is nominal wage and $R_{t+k}$ is nominal interest rate at time $t+k$.

The government collects lump-sum taxes, finances a given level of government expenditures $(g)$, and issues money and nominal bonds $\left(b^{h}\right)$. The government budget constraint:

$$
g+R_{t-1} b_{t-1}^{h} \pi_{t}^{-1}+m_{t-1} \pi_{t}^{-1}=m_{t}+\tau_{t}+b_{t}^{h}
$$

Net accumulation of foreign assets in the home economy expressed in the home currency is given as:

$$
e_{t} b_{t}^{f h}-b_{t}^{h f}=\frac{p_{t}^{p h}}{p_{t}^{h}} y_{t}-c_{t}^{h}+\frac{e_{t} R_{t-1}^{f}}{\pi_{t}} b_{t-1}^{f h}-\frac{R_{t-1}^{h}}{\pi_{t}} b_{t-1}^{h f}
$$

Simulations of the linearized model are calculated by Sims's (1996) gensys procedure for Matlab.

Calibration corresponds to the literature: $\phi_{2}=1$; Leeper (1993) $\gamma=0.5$; corresponding to Blinder (1994) $\rho$ is approximately 0.2. $\mu$ is chosen to be 10 (slightly higher than Rotemberg and Woodford, 1997). I assume $\alpha=2, \beta=0.95$ and $\omega=0.05$ (see Lucas, 1988).

8 ) Including both inflation and depreciation targeting in equation (1) is in the context of New Zealand discussed in Mikek (2003). 
Finally, the specification of the reaction function as in (1) allows for an interpretation of $\theta$ including the capital in/outflow. Capital flows are of extreme importance for the small economy. ${ }^{\text {9) }}$ Through the uncovered interest rate, they affect the simultaneous determination of both exchange rate and interest rate. The structure of the model with the specification (1) that incorporates uncovered interest rate parity allows for such an endogenous interaction between the variables.

\section{Fiscal Policy Reaction Function}

During the first half of 2003 , government revenues grew by $17.5 \%$ while expenditures grew by only $9.9 \%$. Similar are estimated figures for the whole year (growth of revenues by $19 \%$ and expenditures by $12 \%$ - see MF, 2003). The expected tax reform will raise the effective tax rate. From this we conjecture that the fiscal policy is restrictive and trying to limit the deficits and the growth of public debt.

Figure 3 illustrates the difference between Slovenian and European budget deficits. The deficit in Slovenia in 2002 reached $3 \%$, which hardly met the Maastricht criterion. ${ }^{10)}$ Possible revenues from selling government assets due to privatization of some larger companies (such as banks and insurance companies) should make the fiscal position easier. However, a one-off inflow cannot be used for long run financing of the debt. This is true especially in a small country because it has strong monetary effects.

Figure 3

Budget Deficit in Europe and in Slovenia (public finance outcome in \% of GDP)

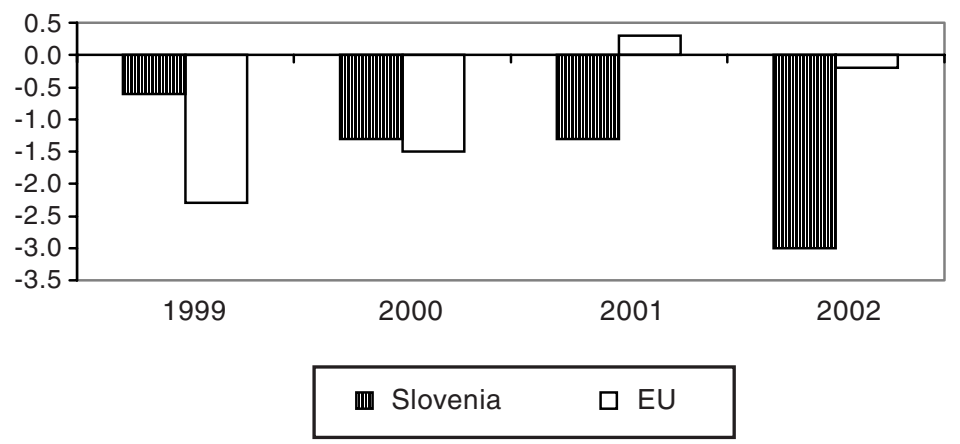

Source: IMAD, 2003.

The public debt in Slovenia (under $30 \%$ of GDP) is much lower than in average country in the EU-15 (average about $62 \%$ of GDP in October 2003). Despite its low

9) The policy of the Slovenian central bank regarding the capital surges is analysed in Oplotnik (2003). He finds that "Empirical results indicated that BaS quite successfully mitigated listed effects of excessive foreign currency inflows during the last decade" (p. 217). The same conclusion can be drawn from Figure 1.

10) Mencinger and Mrak (2003) review the EU fiscal implications for Slovenia and find that "overall fiscal effects of the EU accession will be more or less neutral in the $2004-2006$ period if the calculated (and realised) net inflow from the EU budget amount to at least 0.5 per cent of GDP which matches indirect negative fiscal effects such as reduced budget revenues from VAT and customs duties estimated as well at 0.5 per cent of GDP” (p. 2). 
level, the recent dynamics of the public debt are not encouraging. Table 2 shows the growth of the ratio debt/GDP for selected small European countries. In Slovenia this ratio grew by $9.8 \%$ and was surpassed only by Czech Republic. In contrast, with a large jump in the ratio in Slovenia, the public debt in the EU-15 was decreasing during the period 1999 - 2002 (most notably in Ireland and Denmark).

Table 2

Increase in the Share of Public Debt in GDP and Deficits in 2002 for Selected Small European Countries

\begin{tabular}{|l|c|c|}
\hline & Increase of the share debt/GDP in \% & Deficit in 2002 \\
\hline Austria & 0.59 & -0.6 \\
\hline Denmark & -14.15 & 2.1 \\
\hline Finland & -9.15 & 4.2 \\
\hline Greece & -0.48 & -1.2 \\
\hline Ireland & -33.33 & -0.2 \\
\hline Netherlands & -16.96 & -1.6 \\
\hline Portugal & 7.00 & -2.7 \\
\hline EU-15 & -0.30 & -0.2 \\
\hline Czech Republic & 86.90 & -3.9 \\
\hline Hungary & -7.70 & -9.2 \\
\hline Poland & -2.11 & -4.1 \\
\hline Slovenia & 9.80 & -3.0 \\
\hline
\end{tabular}

Source: IMAD, 2003.

Although the public debt in Slovenia is relatively low, the deficits have increased considerably. In such circumstances the Maastricht criteria require that fiscal policy take a restrictive role and strongly repond to such dynamics. This is captured by large $\gamma$ in equation (8), which describes the behaviour of fiscal policy:

$$
\tau_{t}=\gamma_{0}+\gamma b_{t-1}+\psi_{t}
$$

$\tau_{t}$ represents lump-sum taxes, $b_{t-1}$ is outstanding public debt, ${ }^{11)} \psi_{t}$ is a stochastic shock (with standard normal distribution), $\gamma_{0}$ and $\gamma$ are parameters. ${ }^{12)}$ Relatively large $\gamma$ thus means that the fiscal authority strongly responds to change in outstanding debt (deficits). I follow Woodford (1994) and call this kind of fiscal regime Ricardian. Here fiscal policy meets the intertemporal budget constraint by adjusting future budget revenues as compared to fulfilling the constraint through the inflation tax or

11) In the simulation, the variables are percentage deviations from a steady state, which means that we actually deal with the change in public debt.

12) A given level of government expenditures is assumed and therefore $\tau_{t}$ shows budget surpluses. Similarly as in Leeper (1991) and others the lump sum taxes and the given level of government expenditures in equation (8) should, of course, be understood as a convenient modelling simplification. 
devaluation of home currency in a non-Ricardian regime (some details can be found in e.g. Daniel, 2001 or Mikek, 2001.

To summarize, the dynamics of the Slovenian budget deficit and Maastricht criteria require a restrictive fiscal policy with a strong response to changes in public debt and deficits. This further implies large $\gamma$ in equation (8).

\section{Simulation}

Here I present some simulation results for different possible policy combinations. Policy combination is described as the choice of the response parameters $\alpha$ and $\gamma$ in equations (1) and (8). For some values of the parameters, the solution does not exist. This happens when neither of the policies meets the intertemporal government budget constraint (check, for example, Daniel, 2001). In contrast, some policy combinations do not produce a unique solution if both policies are potentially willing to fulfill the intertemporal budget constraint. Here we will focus on the realistic possibilities with unique solutions. They are obtained for two regimes. The first is the Ricardian regime with strong response of the monetary authority to devaluation and strong response of the fiscal authority to changes in the debt (large $\alpha$ and $\gamma$ ). The second is a non-Ricardian regime with weak response of the fiscal authority to debt changes, and the monetary authority not responding strongly to changes in depreciation (small $\alpha$ and $\gamma$ ).

In Figure 4 some simulation results for monetary and fiscal shock are presented (some details of the model developed in Mikek, 2001). The first row shows the impulse responses for the Ricardian regime and shock to nominal interest rate. As mentioned before, an increase in $\theta$ could be interpreted (among other possible interpretations) as a capital in- or outflow. Massive capital outflow would increase the nominal interest and start the endogenous process of simultaneous determination for interest rate, depreciation, and inflation. As can be seen in the first row of Figure 4 , on impact an increase of the interest rate causes both appreciation and reduction of the inflation rate. A lower exchange rate favorably contributes to lower inflation (since it reduces import prices). Lower inflation increases the real value of bonds.

Through the uncovered interest parity, the exchange rate depreciates in the period $t+1$. The dynamics of the exchange rate thus show Dornbush (1976) type overshooting. Due to the strong reaction of the monetary authority (large $\alpha$ ), the exchange rate depreciates only by a moderate amount at time $t+1$, and inflation also returns to its steady state level quickly. Since the shock is temporary, the interest rates are back at the previous levels at $t+1$. The decrease in real interest rate encourages consumption, and the monetary authority, through buying, reduces the quantity of bonds.

In the Ricardian regime, however, the fiscal shock (an increase in $\psi$ ) is just a swap of future taxes for current taxes and Ricardian equivalence holds. Therefore the shock affects only bonds (as shown in the third row of Figure 4). They decrease on impact and then gradually return to the steady state. ${ }^{13)}$

The findings for the Ricardian regime are in strong contrast to those for a nonRicardian regime. The second row presents the impulse responses for the monetary shock $(\theta)$. Similarly as above, on impact the currency appreciates, inflation drops,

13) Similar to the findings of Leeper (1991) for a closed economy. Such a setting is frequently found in models that disregard the interactions between monetary and fiscal policy, e.g. Obstfeld and Rogoff (1996) or Corsetti and Pesenti (1998). 
Figure 4

Impulse Responses

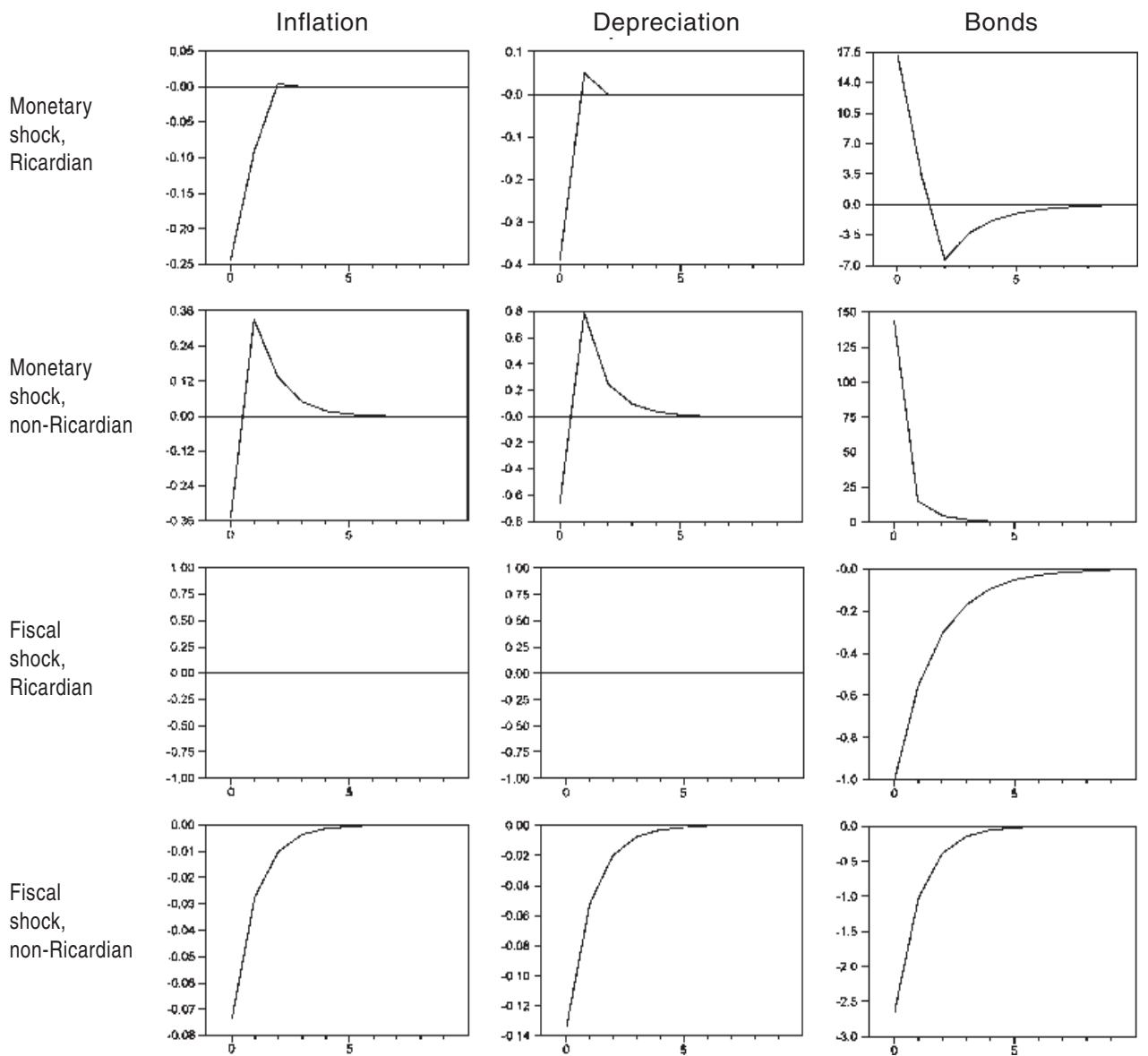

and bonds surge. However, the dynamics are very different. At $t+1$ the exchange rate depreciates much more strongly than before. Along with it, the inflation rate also jumps. This is needed for the appropriate reduction of the real value of current assets to meet the government intertemporal budget constraint. In this regime the agents perceive additional bonds at time $t$ as additional wealth, increase aggregate demand and, given the aggregate demand, this results in the price increase. ${ }^{14)}$

The fiscal shock $(\psi)$ in a non-Ricardian world has starkly different consequences, as shown in the last row of Figure 4. Here the fiscal shock reduces the inflation rate and causes appreciation of the currency. But the fiscal authority now does not adjust taxes and therefore the real interest rate increases to assure that the intertemporal budget constraint is met. This depresses aggregate demand and therefore

14) The results are similar to Woodford (1996), although his discussion remains limited to the closed economy. 
reduces the price level and depreciation. The variables gradually return to their steady state values.

In summary, the price level depends on total government liabilities. For a nonRicardian regime, this means that expansionary fiscal policy leads in inflation and depreciation. Therefore the non-Ricardian fiscal policy is not compatible with the stabilization of the exchange rate. Furthermore, the expansionary fiscal policy is also incompatible with participation in the ERM2 and later in the EMU.

It seems that Slovenian policy makers are aware of this fact. The fiscal policy has recently operated cooperatively with the attempts of the central bank to reduce inflation and stabilize the exchange rate. The temptation for a more extensive use of fiscal stimuli to promote economic growth in the economies that are joining the EU will certainly be limited by the need to stabilize the exchange rate.

\section{米}

The results of the simulation show that the fiscal policy that does not respond strongly to changes in public debt and deficits is not compatible with the stabilization of the exchange rate. The latter is a necessary condition for an economy to join the EMU and should be achieved prior to and during ERM2 participation. The fiscal policy that does not behave sufficiently restrictively would undermine the attempts of the central bank at exchange rate stabilization. Our interpretation is based on the fiscal theory of the price determination that links of total government liabilities and the price level. Slovenian fiscal policy has recently behaved in a cooperatively fashion. Therefore we conjecture that it is aware of the need for compatible fiscal and monetary policies.

\section{References}

Bergin, P. R. (1998), "Fiscal Solvency and Price Level Determination." Mimeo, University of California, Davis.

Blinder, A. (1994), "On Sticky Prices: Academic Theories Meet Real World," in Mankiw, N. G., ed., Monetary Policy. Chicago: University of Chicago Press, pp. 117-150.

Bole, V. (2001), "Disinflation and Labor Market Distortions: Lessons from Slovenia." Ljubljana, Ekonomski institut Pravne fakultete, EIPF Working Papers. pp. 23-43. (2003), "Monetary Policy during the Countdown (in Slovenian)." Gospodarska gibanja, (346),

BaS (2003), "Implementation of the Short-run Monetary Policy Directives" [online]. Ljubljana, Bank of Slovenia (http://www.bsi.si/).

Calvo, G. A. (1983), "Staggered Prices in a Utility-maximizing Framework." Journal of Monetary Economics, 12, pp. 383-398.

Cochran, J. H. (1998), "A Frictionless View of U.S. Inflation." Mimeo, University of Chicago.

Corker, R., Beaumont, C., van Elkan, R., lakova, D. (2000), "Exchange Rate Regimes in Selected Advanced Transition Economies - Coping with Transition, Capital Inflows, and EU Accession." Washington, International Monetary Fund, IMF Policy Discussion Paper No. 00/3.

Corsetti, G., Pesenti, P. (1998), "Welfare and Macroeconomic Interdependence." Cambridge, MA, NBER, Working Paper No. 6307.

Daniel, B. C. (2001), "The Fiscal Theory of the Price Level in an Open Economy." Journal of Monetary Economics, 48, pp. 293-308.

Dixit, A., Stiglitz, J. (1977), "Monopolistic Competition and Optimum Product Diversity." American Economic Review, 67, pp. 297-308.

Dornbusch, R. (1976), "Expectations and Exchange Rate Dynamics." Journal of Political Economy, 84, pp. 1161-1176. 
EC (2003), "The EU Economy 2003 Review” [online]. European Economy, (6) (http://europa.eu.int/ comm/economy_finance/publications/european_economy/2003/statannex0203_en.pdf).

EUROSTAT (2003), [online] (http://europa.eu.int/comm/eurostat/).

IMAD (2003), "Ekonomic Mirror" (in Slovenian) [online]. Ljubljana, Institute for Macroeconomic Analyses and Development (http://www.gov.si/zmar/index.html).

Leeper, E. M. (1991), "Equilibria under 'Active' and 'Passive' Monetary and Fiscal Policies." Journal of Monetary Economics, 27, pp. 129-147.

(1993), "The Policy Tango: toward a Holistic View of Monetary and Fiscal Effects."

Economic Review, 78, pp. 1-27.

Loyo, E. (1997), "The Wealth Effects of Monetary Policy and Brazilian Inflation." Mimeo, Princeton University.

Lucas, R. E. (1988), "Money Demand in the United States: A Quantitative Review." Carnegie-Rochester Conference Series on Public Policy, 29, pp. 137-168.

Mencinger, J. (2002), "Nominal and Real Convergence of the EU and EMU Candidate Countries (in Slovenian)." Gospodarska gibanja, (340), pp. 21-39.

Mencinger, J., Mrak, M. (2003), "Fiscal Policy, Public Debt, and EU Fiscal Implications." Mimeo, Univesity of Ljubljana, Slovenia.

MF (2003), "Bulletin of Public Finance" [online]. Ljubljana, Ministry of Finance (http://www.gov.si/mf/). Mikek, P. (2001), "Monetary and Fiscal Policy and the Price Level in an Open Economy" (in Slovenian). Maribor, Ekonomsko-poslovna fakulteta. (2003), "Inflation Targeting and Switch of Fiscal Regime in New Zealand." Applied Economics, 36, pp. 165-172.

Obstfeld, M., Rogoff, K. (1995), "Exchange Rate Dynamics Redux." Journal of Political Economy, 103, pp. 624-660.

MIT Press.

(1996), Foundations of International Macroeconomics. Cambridge, MA: The

Oplotnik, Ž. (2003), "Bank of Slovenia Adjustment Policy to Surges in Capital Flows." Prague Economic Papers, 12(3), pp. 217-232.

Rotemberg, J. J., Woodford, M. (1997), "An Optimization-based Econometric Framework for the Evaluation of Monetary Policy." Mimeo, Princeton University.

Sargent, T. J., Wallace, N. (1981), "Some Unpleasant Monetarist Arithmetic." Federal Reserve Bank of Minneapolis Quarterly Review, Fall, pp. 1- 17.

Sims, C. A. (1994), "A Simple Model for Study of the Determination of the Price Level and the Interaction of Monetary and Fiscal Policy." Economic Theory, 38(4), pp. 381-399.

(1996), "Solving Linear Rational Expectations Models." Mimeo, Yale University.

Svensson, L. E. O. (1998), "Open-economy Inflation Targeting." Cambridge, MA, NBER, Working Paper No. 6545.

Štiblar, F. (2003), "The EU Expansion - Merger or Take-ower?" (in Slovenian). Gospodarska gibanja, (348), pp. 28-47.

Woodford, M. (1994), "Monetary Policy and Price Level Determinacy in a Cash-in-Advance Economy". Economic Theory, 4, pp. 345-380.

(1996), "Control of the Public Debt: a Requirement for Price Stability?" Cambridge, MA, NBER, Working Paper No. 5685. 